\title{
demandia
}

\section{BRANDING EMOSIONAL PADA VISUALISASI IKLAN TELEVISI WULING CONFERO $S$}

\author{
Muhammad Hidayattuloh ${ }^{1}$, Iman Sumargono ${ }^{2}$ \\ ${ }^{1,2}$ Desain Komunikasi Visual, Fakultas Industri Kreatif, Universitas Telkom \\ Jl. Telekomunikasi No. 1, Terusan Buah Batu, Bandung, 40257, Indonesia \\ hidayattuloh@telkomuniversity.ac.id ${ }^{1}$, imansumargono@ telkomuniversity.ac.id ${ }^{2}$

\begin{abstract}
Abstrak: Hadirnya kendaraan roda empat berjenis small mpv, mendorong berbagai merek untuk memproduksi dan memasarkan jenis kendaraan tersebut. Dalam mendukung pemasaran, iklan digunakan untuk menarik minat konsumen. Wuling Motor menghadirkan Confero S sebagai kedaraan small MPV di Indonesia. Untuk menarik minat konsumen, Wuling menghadirkan iklan Confero S "The Real Spacious Family MPV, As Comfort As Home" yang berdurasi 60 detik. Pada iklan tersebut menampilkan sisi emosional berkendara yang dipadukan dengan fitur yang ada pada kendaraan. Melalui teori branding emosional dengan pendekatan panca indera yang dikemukakan oleh Marc Gobe, maka pada penelitian ini akan mengkaji bagaimana pengaplikasian teori emosional branding pada visualisasi iklan televisi tersebut. Selain dari itu, penelitian ini akan menelaah bentuk branding emosional dengan mengkaji visualisasi adegan dan narasi yang ada pada iklan. Hal tersebut bertujuan untuk mengetahui aspek apa saja yang harus diperhatikan dalam merancang iklan melalui pendekatan teori branding emosional. Dari penelitian ini mendapatkan simpulan bahwa branding emosional pada iklan televisi konsumen dengan memperhatikan atribut visual seperti warna, tekstur, maupun adegan pada iklan yang dihubungkan dengan fitur kendaraan, mampu meningkatkan branding emosional bagi yang melihatnya. Sedangkan narasi yang dijadikan sebagai voice over mampu mendukung pesan utama iklan yang memudahkan konsumen untuk memahami maksud maupun pesan dalan iklan tersebut.
\end{abstract}

Kata Kunci: branding, branding emosional, iklan, panca indera, Confero $S$

Abstract: The presence of small MPV four-wheeled vehicles encourages various brands to produce and promoting these types of vehicles. To support their marketing activities, advertising is used to attract the consumer interest. As Wuling Motor introduced Confero $S$ as a small MPV vehicle in Indonesia, it presented a 60-second ad Confero $S$ "The Real Spacious Family MPV, As Comfort As Home". The ad shows the emotional side of driving combined with the features available on the vehicle. Through theory of emotional branding with the sensory approach proposed by Marc Gobe, this paper examined the form of emotional branding in these advertisements by analyzing the visualization of scenes and narratives in tv commercial. It aims to study the form of emotional branding in advertising and to recognize what aspects must be considered in designing advertising through the approach of emotional branding theory. The result concludes that emotional branding on the ad which emphasizing visual attributes such as colors, textures, and scenes in the advertisement associated with vehicle features can increase emotional branding for those who see it. While the narration used as voice over has supported the ads in order to ease the consumers to understand the main message in the tv commercial.

Keywords: branding, emotional branding, advertising, five senses, Confero $S$ 


\section{demandia}

\section{PENDAHULUAN}

Kendaraan roda empat di Indonesia, memiliki pertumbuhan yang sangat tinggi. Tingginya minat masyarakat yang didukung dengan kebutuhan mobilitas yang cukup tinggi mengakibatkan hadirnya beragam varian merek kendaraan roda empat yang bersaing di pasar Indonesia. Sebagai produsen kendaraan roda empat yang baru muncul di Indonesia, Wuling Motor memiliki produk Confero S sebagai kendaraan berjenis small MPV dengan konfigurasi mesin sebesar 1500cc. Pada dasarnya, Confero S akan bersaing dengan merek yang sudah hadir lebih dulu di Indonesia semisal Toyota Avanza, Daihatsu Xenia, Suzuki Ertiga, maupun Honda Mobilio. Meskipun bersaing dengan kendaraan asal negara Jepang, Wuling berhasil masuk dalam daftar 10 besar kendaraan terlaris di Indonesia pada tahun 2018. Hal tersebut tidak lepas dari tingginya belanja iklan televisi yang dilakukan oleh Wuling (Dabu 2017). Selain dari itu dalam merespon pasar Indonesia, Wuling menyediakan layanan purna jual di sejumlah wilayah di Indonesia (Ravel 2017).

Dalam meningkatkan promosi maupun publikasi, pabrikan kendaraan masih menggunakan iklan televisi sebagai sarana untuk mempromosikan produknya. Hal ini tidak lepas dari peran media televisi yang masih memiliki reputasi yang baik serta jangkauannya yang luas (Gunawan 2015). Dalam mempromosikan produknya, Wuling Motor menghadirkan iklan televisi dimana secara umum, iklan mobil Wuling memiliki reputasi yang cukup baik di mata konsumen. Hal ini terlihat pada penelitian yang dilakukan Kenang Araspati yang mengungkapkan bahwa iklan mobil Wuling memiliki audio dan video yang menarik di mata konsumen dan mampu menarik perhatian konsumen (Andraspati dan Trenggana 2019). Selain dari itu, penelitian yang dilakukan oleh Suryo, Suddin, dan Widajanti (2019), mengungkapkan bahwa visualisasi iklan yang menekankan pada aspek teknologi juga lebih diminati oleh konsumen. Berbeda dengan merek kendaraan roda empat lainnya yang lebih mengedepankan fitur teknologi yang diusung dalam visualisasi iklannya, tampilan iklan Wuling Confero $\mathrm{S}$ 
dengan judul "THE REAL SPACIOUS FAMILY MPV, AS COMFORT AS HOME", lebih menekankan pada nilai emosional berkendara bagi konsumen yang dihubungkan dengan tampilan fitur teknologi yang ada pada kendaraan tersebut. Hadirnya iklan ini dapat menjadi objek penelitian mengenai branding emosional yang disajikan dalam bentuk iklan televisi.

Terdapat beberapa penelitian sebelumnya mengenai objek penelitian yang sama. Salah satunya dengan judul "Pengaruh Harga, Iklan, Citra Merek, dan Pelayanan Purna Jual Terhadap Pembelian Mobil Wuling di Wilayah Surakarta" yang dilakukan oleh Suryo, Suddin, dan Widajanti (2019). Penelitian tersebut mengungkapkan bahwa keputusan pembelian untuk suatu merek kendaraan masih belum konsisten/ terjadi gap antara pengaruh harga, iklan, citra merek, dan layanan purna jual. Menggunakan metode populasi dan sampel, populasi yang digunakan merupakan pembeli mobil Wuling di kawasan Surakarta pada tahun 2018 yang berjumlah 385 orang. Sedangkan sampel yang digunakan bersifat acak sebanyak $25 \%$ dari total populasi. Hasilnya menyimpulkan bahwa harga, iklan, dan citra merek tidak berpengaruh terhadap pembelian sehingga disarankan agar iklan mobil Wuling menampilkan teknologi yang diusungnya (Suryo, Suddin, dan Widajanti 2019). Selain dari itu, penelitian lain dengan judul "Pengaruh Iklan Televisi Wuling Motor Terhadap Pembelian Konsumen di Kota Bandung" telah dilakukan oleh Andraspati dan Trenggana di tahun 2019. Penelitian tersebut bertujuan untuk mengetahui ada tidaknya pengaruh iklan pada televisi dan citra merek terhadap minat beli masyarakat. Penelitian ini menggunakan metode kuantitatif yang mengukur iklan televisi dari segi audio dan video serta keputusan pembelian yang dilihat dari pengenalan masalah, pencarian informasi, pilihan alternatif, keputusan pembelian, perilaku pasca pembelian. Hasil penelitian ini mengungkapkan bahwa iklan televisi Wuling termasuk baik di mata konsumen dan mempengaruhi keputusan pembelian di Kota Bandung (Andraspati dan Trenggana 2019). 
Di sisi lain, terdapat pula penelitian mengenai emotional branding yang membahas penerapan emotional branding pada iklan TVC Aqua versi "It's in Me". Pada penelitian tersebut menggunakan teori sepuluh perintah emotional branding yang menggambarkan adanya konsep branding tradisional dengan dimensi emosional yang diperlukan oleh brand agar menjadi brand yang ekspresif sehingga mampu menarik konsumen. Adapun sepuluh perintah emotional branding tersebut yaitu: (1) Dari konsumen menjadi manusia, (2) Dari produk menuju pengalaman, (3) Dari kejujuran menuju kepercayaan, (4) dari kualitas menuju preferensi, (5) Dari kemasyhuran menuju aspirasi, (6) dari identitas menuju kepribadian, (7) dari fungsi menuju perasaan, (8) dari ubikuitas menuju kehadiran, (9) dari komunikasi menuju dialog, dan (10) dari pelayanan menuju hubungan. Menggunakan metode kualitatif, penelitian tersebut menyimpulkan bahwa penerapan emotional branding pada iklan TVC Aqua tersebut belum dirasakan oleh semua pihak. Adapun informan yang merasakan emotional branding pada iklan tersebut berpendapat bahwa iklan Aqua "It's in Me" memberikan motivasi yang baik dalam menjalankan hidup sehat atau untuk hidup berkarya seperti public figur yang ada dalam iklan tersebut (Rachmayanti dan Pamungkas 2017). Penelitian lain mengenai emotional branding dilakukan oleh Kusuma dan Purnomo (2020) dengan judul "Emotional Branding Dalam Strategi Pemasaran Kolaborasi: Studi Kasus Desain Kemasan Mizzu Khong Guan Face Palette". Penelitian tersebut bertujuan untuk mengetahui bagaimana emotional branding bekerja pada suatu tampilan kemasan dengan menerapkan strategi pemasaran kolaboratif. Penelitian tersebut menggunakan metode deskriptif kualitatif dengan objek penelitian Mizzu Cosmetics versi Khong Guan Face Pallete. Dalam penelitiannya mengemukakan bahwa aspek emotional branding dapat ditingkatkan dengan tambahan visual dari ilustrasi produk yang memancing panca indera dan meningkatkan rasa penasaran. Penelitian tersebut mendapatkan kesimpulan bahwa merancang desain kemasan yang memiliki nilai ikonik dan emosional dalam benak ingatan audiens 
terhadap suatu produk akan merangsang panca indera untuk memunculkan rasa penasaran dan keterlibatan emosi (Kusuma dan Purnomo 2020).

Dari ulasan serangkaian penelitian di atas mengenai aspek visualisasi iklan televisi Mobil Wuling dan peranan panca indera dalam membangun emotional branding, maka penelitian ini memadukan kedua hal tersebut ke dalam objek penelitian Iklan Televisi Wuling Confero S: "THE REAL SPACIOUS FAMILY MPV, AS COMFORT AS HOME". Di mana fokus penelitian tidak hanya menganalisis visualisasi fitur teknologinya, namun juga mengkaji bagaimana visualisasi tersebut mampu mempengaruhi panca indera sebagaimana kesesuaian teori branding emosional dari Marc Gobe (2010). Penelitian ini diharapkan memiliki kontribusi yang baik dan bisa digunakan sebagai rujukan keilmuan desain komunikasi visual dalam hal penerapan branding emosional pada visualisasi scene maupun voice over yang terdapat pada iklan televisi.

\section{LANDASAN TEORI}

Secara umum, brand merupakan suatu citra, kredibilitas, karakter, maupun kesan terhadap suatu produk yang hidup dalam pikiran konsumen (Farid 2017). Dengan hadirnya brand maka konsumen dapat membedakan antara satu produk dengan produk lainnya. Dengan demikian konsumen mengetahui keunikan yang dimiliki oleh produk tersebut. Selain dari itu, brand dapat berperan sebagai jalan pintas yang mampu meyakinkan konsumen dalam mengambil keputusan pembelian suatu produk (Adona, Zerwen, dan Jumyetti 2010). Pemilihan keputusan terhadap suatu brand, tidak lepas dari peranan image terhadap brand yang telah dibangun, karena pada dasarnya brand image mampu memiliki pengaruh yang signifikan terhadap keputusan pembelian suatu produk (Iswanto 2015).

Pada saat ini branding emosional sering digunakan oleh suatu produk dikarenakan mampu mempengaruhi loyalitas maupun kepercayaan konsumen terhadap suatu produk (Wijanarka, Suryoko, dan Widiartanto 2015). Hal tersebut tidak 
lepas dari peranan branding emosional yang mampu menghadirkan rasa suka dan nyaman terhadap suatu produk yang dibentuk oleh perasaan yang bersifat subjektif maupun ekspresif namun sesuai dengan kebutuhan konsumen (Prastika 2013).

Salah satu pilar dalam emotional branding ialah penggunaan panca indera sebagai alat untuk meningkatkan persepsi produk sekaligus meningkatkan ikatan emosi antara produk dengan konsumen. Pengalaman panca indera ini dapat menghadirkan suatu merek melalui rangsangan panca indera yang bertujuan untuk membuka sisi emosional konsumen yang mampu mempererat ikatan antara konsumen dengan merek (Nurseptia dan Trenggana 2019). Dalam pengolahan panca indera sebagai bagian dari branding emosional, maka akan menghadirkan citra, kenikmatan rasa, suara, sentuhan, maupun wangi yang dapat membuat stimulus terkait kesan yang akan hadir dalam memori. Pengalaman yang berhubungan dengan panca indera akan berlangsung secara cepat, kuat, dan mampu mengubah persepsi. Pengalaman panca indera tersebut dapat diolah secara maksimal dalam lingkup toko, pengembangan produk, desain kemasan, maupun iklan (Gobe 2010).

Dalam paparan mengenai aspek panca indera yang dapat dijadikan sebagai metode branding emosional pada suatu iklan, terdapat beberapa unsur panca indera yang dapat digunakan, antara lain: bunyi yang membawa suasana, warna yang menghipnotis/ simbol yang memikat, rasa yang menggiurkan, bentuk yang menyentuh, serta aroma yang menggoda (Gobe 2010).

\section{METODE PENELITIAN}

Metode yang dilakukan pada penelitian ini menggunakan metode kualitatif untuk memberikan deskripsi mengenai objek penelitian. Metode kualitatif sering pula diungkapkan sebagai metode penelitian interpretatif dikarenakan hasil penelitian berhubungan interpretasi yang ditemukan di lapangan. Adapun langkah penelitian kualitatif dengan meneliti kondisi objek, pengumpulan data, analisis data yang bersifat induktif, dan hasil penelitian yang menekankan pada makna (Sugiyono 2016). Selain 
menggunakan metode kualitatif, pada penelitian ini menggunakan teori branding emosional dari Marc Gobe (2010) yang secara spesifik mengenai aspek branding emosional berdasarkan panca indera. Selain dari itu, digunakan teori copywriting maupun desain komunikasi visual untuk mendukung analisis mengenai teks, bentuk, warna, tekstur yang berkaitan dengan objek penelitian.

\section{HASIL DAN PEMBAHASAN}

\section{Objek Penelitian}

Mengingat adanya beberapa versi iklan mobil Wuling, maka yang menjadi objek penelitian ialah iklan Confero S dengan judul "The Real Spacious Family MPV, As Comfort As Home" yang berdurasi kurang lebih 60 detik yang bersumber dari akun resmi youtube Wuling Motor ID. Pada Gambar 1 terlihat adanya situasi liburan yang dilakukan oleh suatu keluarga menggunakan Wuling Confero S. Berdasarkan paparan dari Tomson, liburan pada generasi milenial merupakan suatu gaya hidup yang dapat meningkatkan pengalaman (Silalahi 2019). Di bawah ini, ditampilkan screenshot dari iklan tersebut.
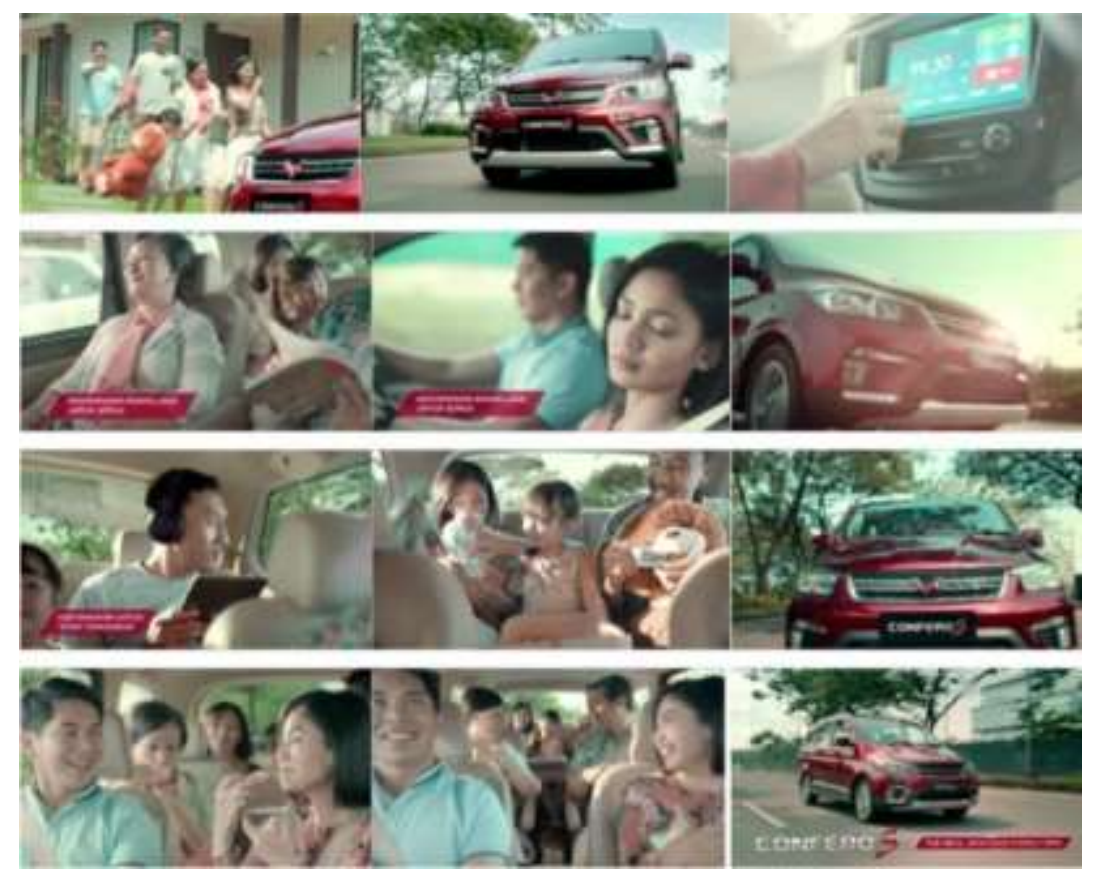

Gambar 1. Screenshot iklan Confero S The Real Spacious Family MPV, As Comfort As Home Sumber: Wuling MotorsID (2017) The Real Spacious Family MPV Confero S available at https://www.youtube.com/watch?v=yGafPeFKLWA accessed 24 juni 202022.00 


\section{Pembahasan}

\section{a. Bunyi yang membawa suasana}

Bunyi merupakan aspek pada panca indera manusia yang memiliki dampak segera dan lebih langsung terhadap suatu ingatan dan emosi. Melalui penerapan bunyi yang terencana dengan baik, mampu memikat emosi dan menarik perhatian (Gobe 2010). Melihat pada iklan Confero S yang menjadi objek penelitian, terdapat bunyi dalam iklan yang berupa alunan musik secara instrumen yang disatukan dengan voice over dengan menjelaskan keunggulan produk baik secara emosional maupun rasional. Hadirnya bunyi baik voice over maupun musik dalam iklan merupakan elemen penting dari suatu iklan televisi (Tanumiharjo, Goenawan, dan Monica 2019).

Mendengarkan voice over pada iklan tersebut yang diuraikan pada Tabel 1, terdapat tiga kalimat yang menjadi pesan, yaitu: (1) Senangnya bila kenyamanan rumah bisa dibawa ke mana saja, (2) Wuling Confero S hadir sebagai mobil keluarga yang lega senyaman rumah Anda, (3) serta Wuling Confero S The Real Spacious Family MPV.

Tabel 1. Analisis copywriting yang menjadi bagian dari audio yang terdapat pada iklan Wuling Confero S

\begin{tabular}{llcl}
\hline No & Kalimat voice over & $\begin{array}{c}\text { Gaya dan jenis kata } \\
\text { copywriting }\end{array}$ & Keterangan \\
\hline 1 & $\begin{array}{l}\text { Senangnya bila kenyamanan } \\
\text { rumah bisa dibawa kemana } \\
\text { saja }\end{array}$ & eksploratif & $\begin{array}{l}\text { Penguatan citra kenyamanan } \\
\text { kendaraan yang disamakan } \\
\text { dengan kenyamanan rumah }\end{array}$ \\
2 & $\begin{array}{l}\text { Wuling Confero S, hadir } \\
\text { sebagai mobil keluarga yang } \\
\text { lega senyaman rumah anda }\end{array}$ & eksploratif & $\begin{array}{l}\text { Penguatan citra ukuran luas } \\
\text { kendaraan yang disamakan ukuran }\end{array}$ \\
Wuling Confero S, the real & & luas rumah \\
spacious family mpv & Memberikan informasi mengenai \\
\hline
\end{tabular}

Sumber: Dokumentasi penulis

Melihat kalimat tersebut berdasarkan sudut pandang copywriting, terdapat dua jenis gaya dan jenis kata dalam copywriting yang digunakan, yaitu explorative dan informative. Eksploratif dalam copywriting merupakan mengulas baik secara fisik maupun psikis suatu produk atau jasa dengan kata-kata yang akurat dan tidak bermakna ganda, tujuan dari eksploratif tersebut ialah untuk menguatkan citra. 
Sedangkan gaya dan jenis kata informatif dalam suatu copywriting merupakan memberikan informasi mengenai produk atau jasa dan didukung suatu data yang menunjang serta disampaikan secara komunikatif (Agustrijanto 2002).

Melihat pada kalimat voice over satu dan dua, terdapat penguatan citra mengenai kenyamanan dan luas ruangan rumah yang disamakan dengan suatu kendaraan. Voice over tersebut didukung dengan visualisasi nilai keluarga seperti kehangatan, keakraban, maupun keceriaan antara anggota keluarga serta didukung dengan aktivitas keseharian di dalam rumah, seperti bercengkrama, beristirahat, maupun keakraban lainnya yang dilakukan di dalam kendaraan. Selain dari itu, keunggulan produk mengenai ruang yang luas, turut divisualkan dengan banyaknya barang pribadi di dalam kendaraan dan tidak mengurangi interaksi antar anggota keluarga.

Jika melihat pada teori branding emosional yang telah dijelaskan pada paragraf sebelumnya, terlihat adanya suatu perencanaan antara kalimat copywriting yang terdapat pada voice over dan visualisasi yang terdapat pada iklan tersebut. Kalimat copywriting dan visualisasi terlihat saling mendukung satu sama lain dalam menekankan image yang ingin dibentuk, dalam hal ini penguatan image mengenai mobil keluarga yang nyaman dan dapat diisi oleh semua anggota keluarga. Hadirnya voice over dan visualisasi tersebut, diharapkan akan menghasilkan ingatan kepada target audiens mengenai suatu merek kendaraan keluarga yang nyaman untuk dikendarai oleh semua anggota keluarga.

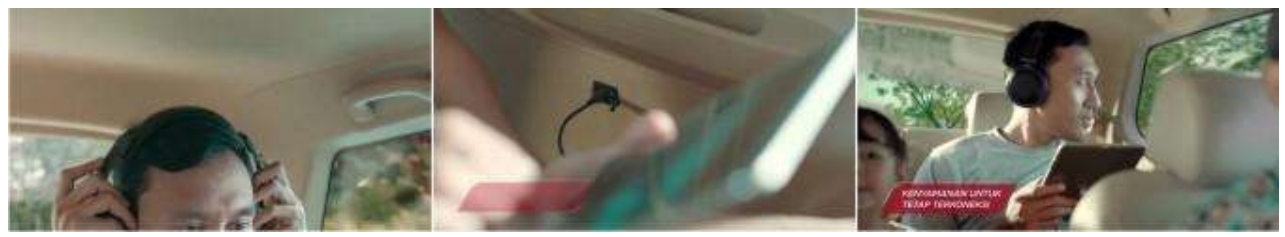

Gambar 2. adegan yang memvisualisasikan fitur USB Charging pada baris paling belakang kendaraan (baris ke-3) dalam mendukung aktivitas yang berhubungan dengan suara pada gadget. Sumber: Wuling MotorsID (2017) The Real Spacious Family MPV Confero S available at https://www.youtube.com/watch?v=yGafPeFKLWA accessed 24 juni 202022.00

Selain penggunaan dari copywriting, penggunaan visualisasi iklan yang terkait dengan suara juga ditampilkan pada scene di detik ke-30 sampai detik ke-33 seperti 
yang terlihat pada Gambar 2 di atas, mengenai fitur USB charging yang terdapat pada kursi penumpang paling belakang (baris ke-3). Dimana pada adegan tersebut terlihat penumpang pada bangku paling belakang mampu melakukan pengisian daya gadget melalui fitur tersebut untuk melakukan aktivitas yang berhubungan dengan suara, melalui headset. Hadirnya visualisasi mengenai fitur pengisian daya pada mobil tersebut sesuai dengan apa yang disampaikan oleh Gobe (2010) bahwa merek harus dengan jelas memperhatikan pesan-pesan solusi sesuai dengan apa yang diperhatikan oleh konsumen.

\section{b. Warna Yang Menghipnotis}

Warna merupakan salah satu elemen secara indra penglihatan yang mampu membangkitkan mood. Dalam perspektif branding melalui warna bukan hanya mengenai cantik atau indah, melainkan mengenai menyampaikan informasi kepada target audiens (Gobe 2010). Melihat pada visualisasi iklan mobil Wuling Confero S, terdapat penggunaan warna yang dominan ke arah orange, biru, warna pastel, serta warna merah seperti yang diuraikan pada table 2 di bawah ini.

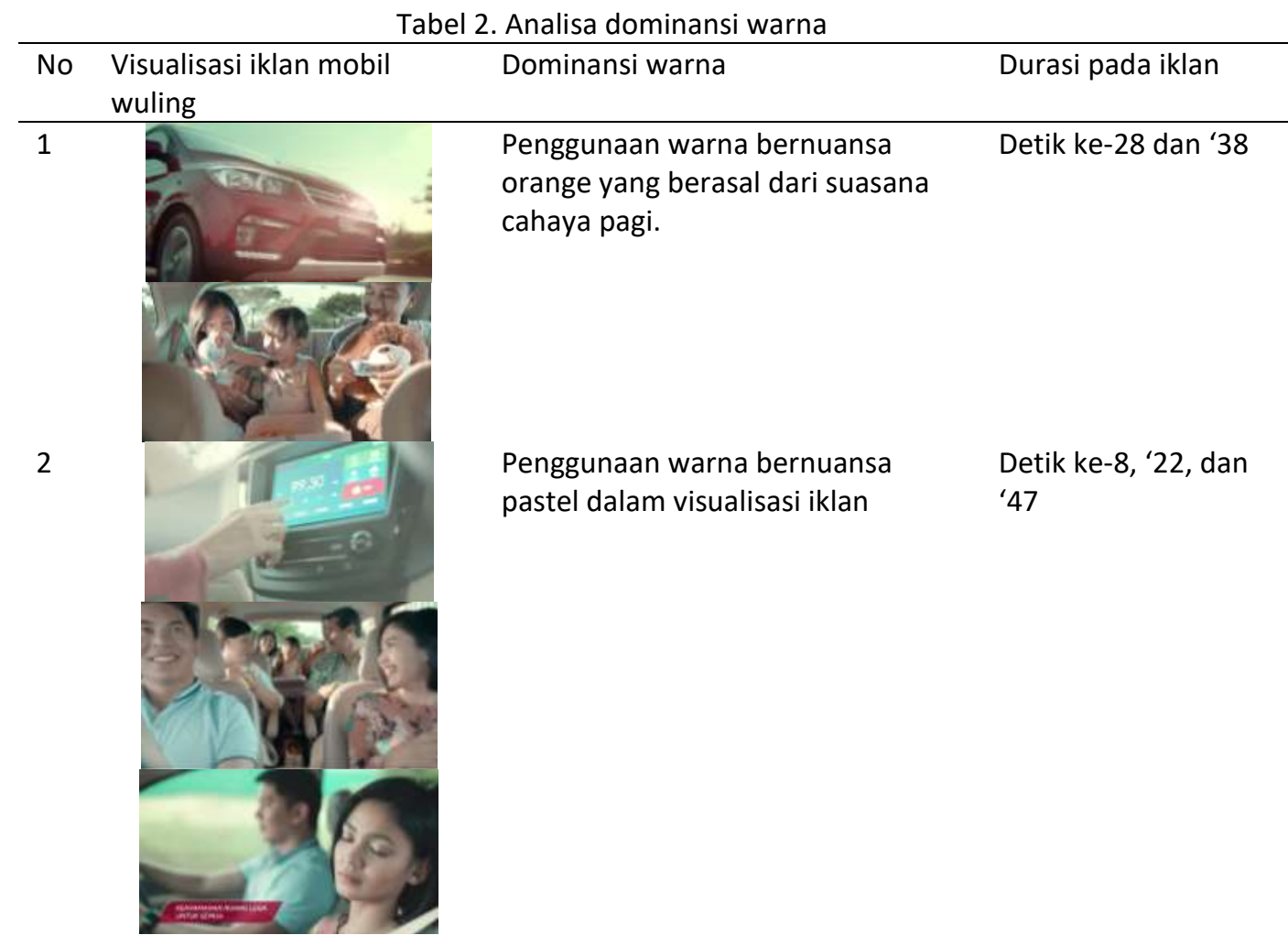


3

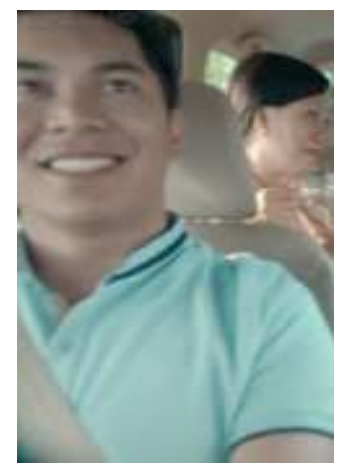

Penggunaan warna bernuansa biru Detik ke-47

dalam visualisasi iklan

Sumber: Wuling MotorsID (2017) The Real Spacious Family MPV Confero S available at https://www.youtube.com/watch?v=yGafPeFKLWA accessed 24 juni 202022.00

Warna pastel merupakan warna yang pudar dikarenakan warna putih yang terlalu dominan (Bishop 2013). Penggunaan warna pastel mampu menghadirkan kenyamanan ketika dipandang (Anto, Andrijanto, dan Akbar 2017). Melihat pada makna warna yang digunakan pada suatu brand, warna orange memiliki arti yang bersahabat dan biru memiliki arti ketenangan (Gobe 2010). Sedangkan dalam keilmuan DKV warna orange memiliki arti energi, keseimbangan, dan kehangatan. Selain dari itu, warna orange lebih memiliki makna hangat, semangat muda, dan menarik (Darmaprawira 2002). Sementara warna biru memiliki arti kepercayaan konservatif, keamanan, teknologi, kebersihan, dan perintah (Kusrianto 2009). Selain itu, warna biru memiliki arti damai, setia, terhormat, lembut dan ikhlas (Darmaprawira 2002). Melihat makna warna tersebut terdapat persamaan makna warna dan visualisasi yang terdapat pada iklan Wuling Confero S dimana nilai teknologi, kehangatan, dan bersahabat seperti yang diuraikan pada Tabel 3 di bawah ini.

Tabel 3. Analisa korelasi makna warna dan visualisasi iklan mobil Wuling Confero $\mathrm{S}$

\begin{tabular}{lll}
\hline No $\begin{array}{l}\text { Warna dan makna } \\
\text { warna }\end{array}$ & $\begin{array}{l}\text { Visualisasi iklan mobil wuling } \\
\text { confer S }\end{array}$ & $\begin{array}{l}\text { Keterangan } \\
\text { arti kepercayaan } \\
\text { konservatif, } \\
\text { keamanan, } \\
\text { teknologi. }\end{array}$ \\
\hline $\begin{array}{l}\text { Biru yang deknologi pada visualisasi } \\
\text { teknologi layar sentuh pada bagian } \\
\text { dashboard serta penyajian USB } \\
\text { charging hingga bagian kursi } \\
\text { paling belakang (baris ketiga). }\end{array}$
\end{tabular}


Orange memiliki arti yang bersahabat, dan ketenangan

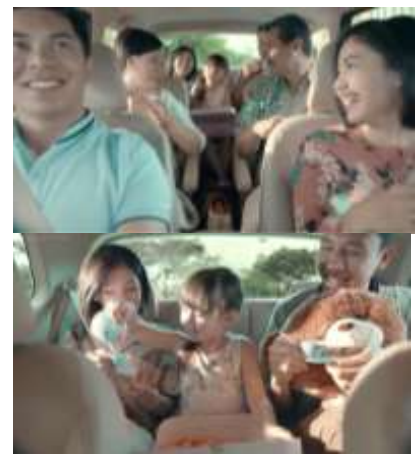

Sumber: Wuling MotorsID (2017) The Real Spacious Family MPV Confero S available at https://www.youtube.com/watch?v=yGafPeFKLWA accessed 24 juni 202022.00
Nilai kehangatan keluarga, dan persahabatan antara anggota keluarga yang dihadirkan pada visualisasi iklan.

Selain menampilkan warna yang telah disebutkan di atas, pada Gambar 3 di bawah yang merupakan bagian dari iklan Confero S, warna merah juga ditampilkan sebagai warna kendaraan yang hadir di iklan tersebut.

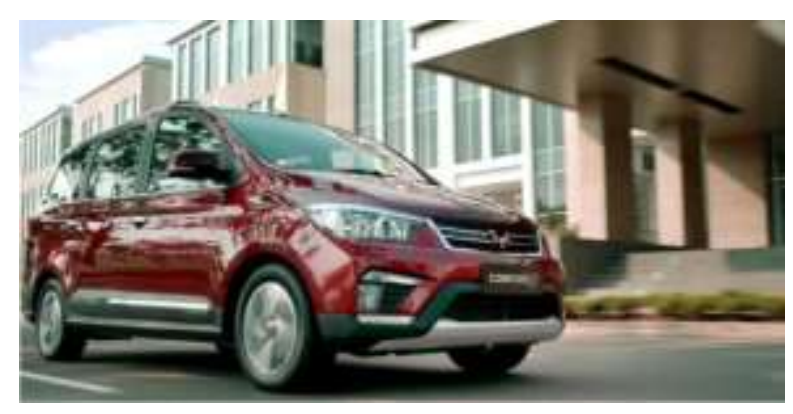

Gambar 3. Visualisasi mobil Wuling Confero S yang hadir pada iklan.

Sumber: Wuling MotorsID (2017) The Real Spacious Family MPV Confero S available at https://www.youtube.com/watch?v=yGafPeFKLWA accessed 24 juni 202022.00

Secara makna, warna merah memiliki arti kekuatan, kehangatan, cinta, bertenaga, agresif, serta bahaya (Kusrianto 2009). Selain dari itu, penggunaan warna merah sejalan dengan warna yang terdapat pada logo Wuling sehingga dapat menjadi identitas dari produk. Penggunaan warna yang sesuai dengan identitas mampu menarik perhatian konsumen sekaligus memudahkan konsumen untuk mengenali produk (Dewi, Hairiza, dan Limbong 2019). Selain dari itu, pemilihan warna merah pada kendaraan yang sesuai dengan warna logo, sejalan dengan apa yang diungkapkan oleh Gobe bahwa pemilihan warna secara tepat dalam mengidentifikasikan logo, produk, maupun tampilan merek dapat merangsang ingatan yang lebih baik terhadap merek yang disampaikan (Gobe 2010). 


\section{c. Visualisasi pada iklan yang berhubungan dengan indera perasa}

Secara umum, rasa akan berhubungan dengan makanan. Pada visualisasi iklan, informasi mengenai rasa, bahan, keunggulan, serta manfaat akan berkaitan dengan informasi suatu produk makanan dan minuman (Musaffak 2015). Makanan merupakan suatu bentuk transaksi sosial yang penuh dengan arti khusus pada suatu kebudayaan. Selain dari itu, menawarkan makanan menunjukan suatu empati, membuat kita merasa lega, dan bahkan memberikan kesenangan (Gobe 2010).

Pada visualisasi iklan Confero S, pemberian makanan atau aktivitas makan secara umum dijadikan salah satu scene pada iklan tersebut. Dari beberapa scene yang ada pada iklan tersebut, terdapat dua buah scene yang berhubungan dengan rasa maupun makanan, yaitu: gesture seolah-olah mencicipi makanan dan minuman dengan media mainan anak-anak, serta dikaitkan dengan aktivitas bercanda bersama anggota keluarga yang dilakukan di dalam kendaraan seperti yang disebutkan pada Tabel 4 di bawah ini.

Tabel 4. Analisa aspek rasa yang berhubungan dengan makanan atau minuman pada visualisasi iklan mobil Wuling Confero $S$

\begin{tabular}{|c|c|c|c|}
\hline No & Visualisasi iklan mobil wuling confer $\mathrm{S}$ & Keterangan & Durasi pada iklan \\
\hline 1 & (n) & $\begin{array}{l}\text { Point } 1 \text { merupakan } \\
\text { aktivitas seolah olah } \\
\text { makan snack bersama } \\
\text { yang dilakukan di dalam } \\
\text { kendaraan dan menjadi } \\
\text { salah satu scene pada } \\
\text { iklan }\end{array}$ & $\begin{array}{l}\text { Detik ke-45 sampai } \\
47\end{array}$ \\
\hline 2 & 1 & $\begin{array}{l}\text { Point } 2 \text { dan } 3 \text { merupakan } \\
\text { aktivitas seolah olah } \\
\text { minum yang } \\
\text { berbarengan dengan } \\
\text { aktifitas bermain dan } \\
\text { dilakukan di dalam } \\
\text { kendaraan menjadi salah } \\
\text { satu scene pada iklan }\end{array}$ & Detik ke-39 \\
\hline
\end{tabular}

Sumber: Wuling MotorsID (2017) The Real Spacious Family MPV Confero S available at https://www.youtube.com/watch?v=yGafPeFKLWA accessed 24 juni 202022.00

Hadirnya scene yang berhubungan dengan rasa maupun makanan, menghadirkan nilai kehangatan, kebersamaan, maupun kesenangan yang ditampilkan dalam bahasa visual. Hal ini memiliki keterkaitan dengan hasil analisis sebelumnya mengenai makna warna yang telah dibahas pada pembahasan 
sebelumnya yang cenderung menekankan nilai kehangatan dan persahabatan antar anggota keluarga yang dilakukan di dalam kendaraan.

\section{d. Membangun Emosional melalui Indera Peraba}

Dalam branding emosional merasakan suatu produk memiliki kedudukan yang penting. Merasakan produk memiliki kaitan dengan kesenangan dari proses memegang maupun memainkan. Selain dari itu, merasakan mampu membayangkan seolah-olah produk tersebut menjadi dimiliki sebelum membelinya (Gobe 2010).

Tabel 5. Analisa bentuk yang menyentuh pada visualisasi iklan mobil Wuling Confero S

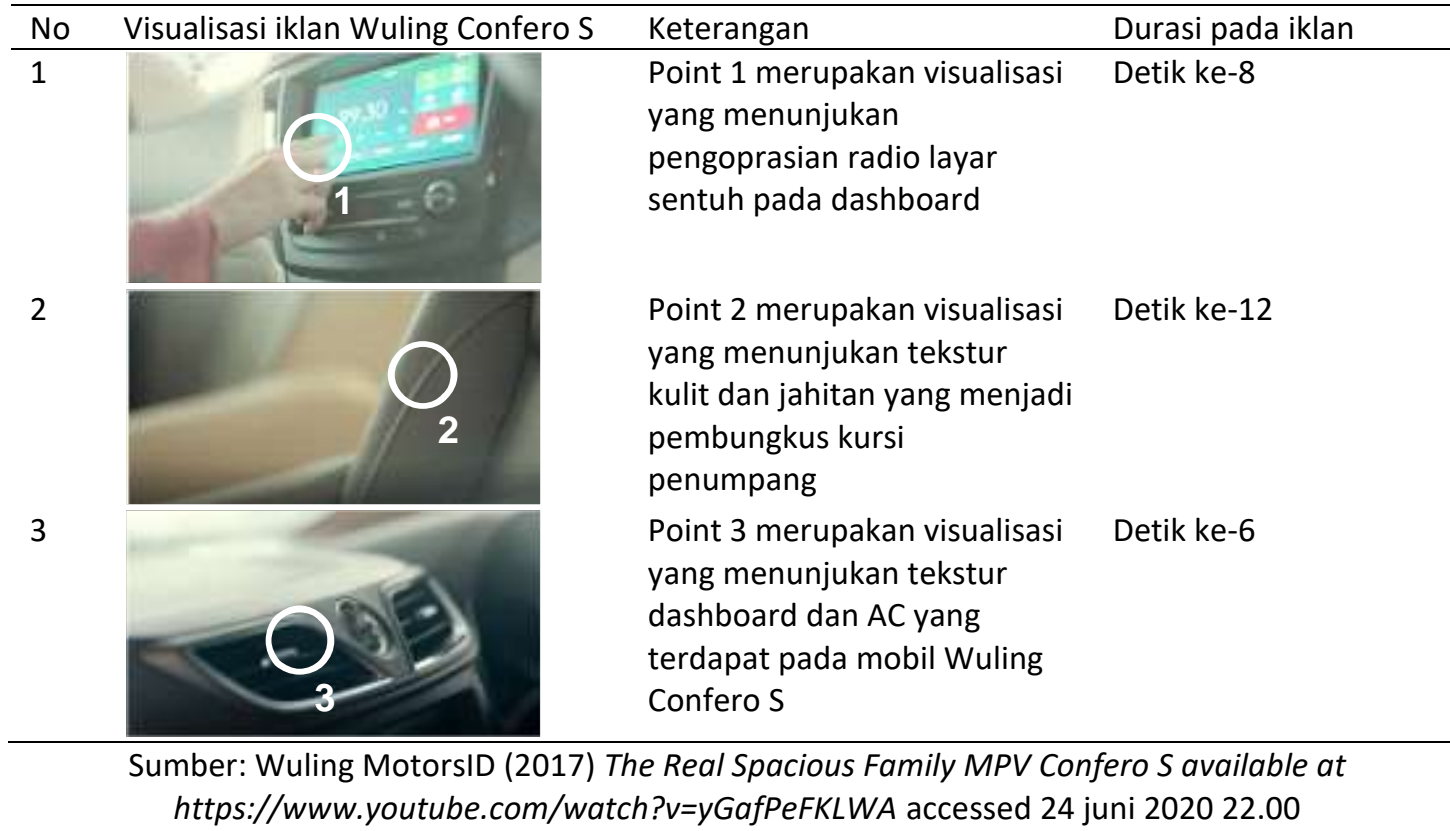

Dalam visualisasi iklan Confero S yang terlihat pada Tabel 5, proses menyentuh produk, diwakilkan dengan scene yang memperlihatkan pengoprasian radio layar sentuh yang terdapat pada dashboard. Hadirnya scene tersebut sekaligus menunjukan keunggulan produk yang akan dirasakan oleh konsumen ketika mereka membeli produk tersebut. Selain memperlihatkan scene mengenai pengoperasian radio layar sentuh, pada iklan Confero $\mathrm{S}$ juga menampilkan tekstur yang terdapat pada bagian kulit pembungkus kursi penumpang dan dashboard. Kusrianto (2009) memaparkan, tekstur dalam desain komunikasi visual merupakan nilai raba dari 
suatu permukaan. Hadirnya scene mengenai tekstur pada bagian kulit pembungkus kursi penumpang dengan menghadirkan detail tekstur dan jahitan yang terdapat kursi penumpang, serta hadirnya scene mengenai tekstur dashboard dengan disertai bagian AC, mampu menunjukan kelebihan produk sekaligus membawa konsumen untuk merasakan produk tersebut melalui visualisasi pada iklan.

Dalam pandangan Gobe, objek maupun interior merupakan suatu desain yang harus ditata agar dapat dijelajahi, dirasakan, dan diekspos (2010). Melihat pada visualisasi iklan Confero S, seperti yang terlihat pada Tabel 6, bentuk mobil tampak depan ditampilkan pada beberapa scene. Pada tampak depan mobil terlihat adanya logo Wuling yang menjadi identitas produk sekaligus menampilkan fitur unggulan yang terdapat pada bagian depan kendaraan seperti projector headlight serta daytime running light. Sedangkan pada interior kendaraan, terdapat scene yang menunjukan bagian AC pada dashboard yang secara visual menyerupai logo Wuling. Hal tersebut merupakan salah satu bentuk pengaplikasian logo pada suatu media, di mana menurut Rustan (2013) logo dapat juga diaplikasikan pada berbagai media yang digunakan oleh perusahaan. Sedangkan dalam perspektif emotional branding, logo memiliki peranan yang lebih luas dari sekedar tampilan pada sudut iklan, logo dapat dimanfaatkan pada tujuan yang lebih luas (Gobe 2010).

Selain dari tampilan AC pada dashboard, dalam Tabel 6 terlihat interior mobil yang luas ditampilkan pada beberapa scene pada iklan tersebut yang menunjukan model berjumlah tujuh orang, yang terdiri atas enam orang dewasa dan satu anakanak dengan beragam aktivitas di dalamnya mulai dari membaca majalah, resep, dan lain sebagainya. Selain dengan menampilkan model tersebut, terdapat scene yang menunjukan kenyamanan ruang duduk penumpang pada baris ketiga. Terlihat pada scene tersebut, jarak antara lulut penumpang di baris ketiga cukup jauh dengan kursi penumpang di depannya. Dalam menunjang keamanan penumpang, pada visualisasi iklan tersebut terlihat adanya scene yang menampilkan fitur sabuk pengaman sampai baris ketiga kendaraan. 
Tabel 6. Analisa eksplorasi objek dan interior kendaraan pada iklan Wuling Confero S

\begin{tabular}{|c|c|c|c|}
\hline No & Visualisasi iklan mobil Wuling Confero S & Keterangan & Durasi pada iklan \\
\hline 1 & 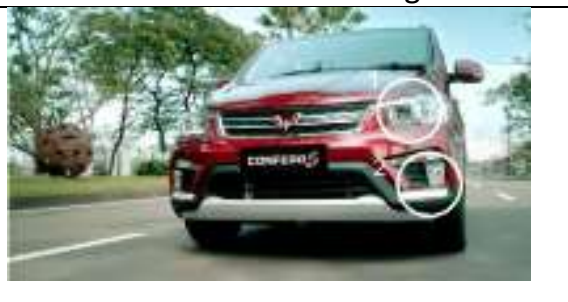 & $\begin{array}{l}\text { Pada visualisasi bentuk } \\
\text { tampak depan kendaraan, } \\
\text { terlihat fitur kendaraan } \\
\text { projector headlight (point1) } \\
\text { dan daytime running light } \\
\text { (point2) yang menjadi fitur } \\
\text { kendaraan di bagian depan }\end{array}$ & $\begin{array}{l}\text { Detik ke-1 sampai } \\
5\end{array}$ \\
\hline 2 & & $\begin{array}{l}\text { Pada bagian interior terlihat } \\
\text { bentuk ac pada dashboard } \\
\text { yang serupa dengan logo } \\
\text { wuling (point } 3 \text { ). }\end{array}$ & Detik ke-6 \\
\hline 3 & & $\begin{array}{l}\text { Visualisasi bagian interior } \\
\text { yang menampilkan ruang } \\
\text { yang luas (tujuh orang } \\
\text { model) serta nyaman } \\
\text { dengan menampilkan } \\
\text { beragam aktivitas pada iklan } \\
\text { seperti beristirahat (point 4), } \\
\text { membaca majalah (point 5), } \\
\text { serta bercengkrama (point 6) } \\
\text { pada satu waktu }\end{array}$ & $\begin{array}{l}\text { Detik ke-14 sampai } \\
18\end{array}$ \\
\hline 4 & & $\begin{array}{l}\text { Pada point } 7 \text { terlihat } \\
\text { visualisasi mengenai luas } \\
\text { serta nyaman kendaraan } \\
\text { dengan menampilkan adegan } \\
\text { ruang duduk yg cukup luas } \\
\text { bagi penumpang. }\end{array}$ & $\begin{array}{l}\text { Detik ke-24 sampai } \\
25\end{array}$ \\
\hline 5 & & $\begin{array}{l}\text { Pada point } 8 \text { terlihat fitur } \\
\text { sabuk pengaman yang ada } \\
\text { sampai baris ketiga } \\
\text { kendaraan. }\end{array}$ & Detik ke-23 \\
\hline
\end{tabular}

Sumber: Wuling MotorsID (2017) The Real Spacious Family MPV Confero S available at https://www.youtube.com/watch?v=yGafPeFKLWA accessed 24 juni 202022.00

Hadirnya visualisasi mengenai tampak depan kendaraan serta interior kendaraan memberikan suatu informasi kepada konsumen mengenai detail produk sekaligus dapat membayangkan produk tersebut sebelum melakukan pembelian. Hal 
ini sejalan dengan apa yang diungkapkan oleh Gobe (2010) bahwa sentuhan terhadap produk, aksesoris, ruangan, bahkan lantai maupun pegangan pintu merupakan suatu dimensi dari pengalaman merek.

\section{e. Aroma sebagai medium komunikasi}

Dalam suatu iklan, aroma maupun rasa dapat digambarkan secara visual untuk mengkomunikasikan suatu produk (Moriarty, Mitchell dan Wells 2011). Selain dari itu, seperti yang disampaikan oleh Marc Gobe (2010) indra penciuman merupakan sarana untuk merasakan aroma yang mampu menghadirkan emosi. Memberikan rangsangan aroma mengenai suasana kamar tidur, dapur, ataupun lingkungan lainnya merupakan bagian yang penting dari proses branding yang dilakukan (Gobe 2010).

Dalam narasi iklan Wuling Confero $S$, kenyamanan rumah merupakan salah satu bagian yang dihadirkan dan dikaitkan dengan produk. Secara narasi, kenyamanan rumah divisualkan dengan berbagai aspek, termasuk memberikan rangsangan secara emosional mengenai situasi istirahat yang kerap dilakukan layaknya di dalam rumah. Melihat pada paragraf sebelumnya, aroma mengenai suasana kamar tidur, pada iklan mobil Wuling juga ditampilkan pada salah satu scene di iklan tersebut seperti yang terlihat pada Gambar 4.

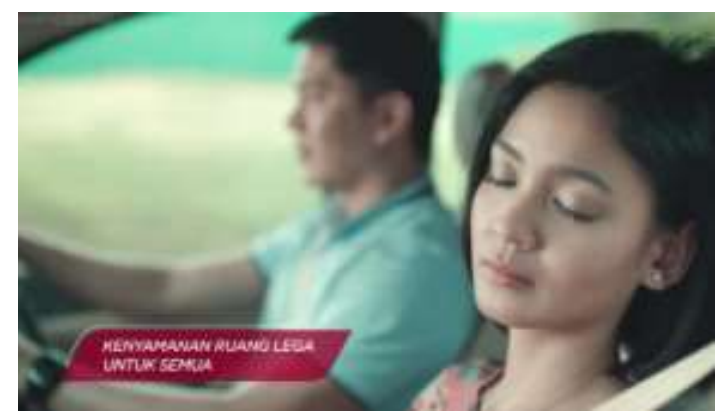

Gambar 4. Visualisasi aktivitas istirahat yang menjadi salah satu scene pada iklan Sumber: Wuling MotorsID (2017) The Real Spacious Family MPV Confero S available at https://www.youtube.com/watch?v=yGafPeFKLWA accessed 24 juni 202022.00

Dalam scene tersebut, terlihat salah satu model tengah tengah tertidur lelap dengan diiringi narasi/voice over "Wuling Confero S hadir sebagai mobil keluarga yang lega senyaman rumah anda". 


\section{KESIMPULAN}

Dalam visualisasi iklan yang mengedepankan nilai branding emosional dengan pendekatan panca indera, terdapat beberapa poin yang mampu dijadikan sebagai acuan. Antara lain ialah penggalian adegan yang disesuaikan dengan aktivitas yang mendukung gaya hidup konsumen serta dihubungkan dengan keunggulan produk untuk menghasilkan pesan iklan yang berhubungan dengan pengalaman terhadap merek. Penggalian atribut visual seperti warna, tekstur, maupun adegan dan situasi yang dihadirkan pada iklan dengan mengacu pada pengalaman panca indera mampu menghadirkan visualisasi iklan yang menarik sekaligus meningkatkan nilai emosi bagi audiens yang melihatnya. Selain dari itu, Penggunaan musik yang diiringi dengan voice over mengenai pesan utama iklan dapat memudahkan konsumen memahami maksud maupun pesan dalam iklan tersebut dan nilai apa yang akan dihadirkan pada iklan. Mengingat penelitian ini menggunakan teori branding emosional dengan sudut pandang desain komunikasi visual, maka aspek musik dapat diteliti oleh peneliti lainnya.

\section{DAFTAR PUSTAKA}

Adona, F., Zerwen, L., \& Jumyetti. 2010. "Kekerasan dalam Emotional Branding Perusahaan Indonesia." Sosiohumaniora 12(3):236-249.

Agustrijanto. 2002. Copywriting Seni Mengasah Kreativitas dan Memahami Bahasa Iklan. Bandung: Remaja Rosdakarya.

Andraspati, K., \& Trenggana, A. F. M. 2019. “Pengaruh Kualitas Produk, Emotional Branding, dan Experiental Marketing Terhadap Loyalitas Konsumen di Koflcuk Bandung." E-Proceeding of Management 6(2):4291-4298.

Anto, P., Andrijanto, M. S., \& Akbar, T. 2017. “Perancangan Buku Pedoman Umum Ejaan Bahasa Indonesia sebagai Media Pembelajaran di Sekolah." Jurnal Desain 4(02):92-99.

Bishop, S. 2013. Panduan Fotografer Warna Cahaya \& Komposisi. Jakarta: Elex Media Komputindo. 
Dabu, P. 2017. Belanja iklan otomotif di TV naik $23 \%$ bulan lalu. www. industri.kontan.co.id/news/belanja-iklan-otomotif-di-tv-naik-23-bulan-lalu (diakses pada 4 november 2020 pukul 20.41)

Darmaprawira, S. 2002. Warna Teori dan Kreativitas Penggunaannya. Bandung: Penerbit ITB.

Dewi, C. M., Hairiza, A., \& Limbong, E. G. 2019. "Warna sebagai Identitas Merek pada Kemasan Makanan Tradisional Kembang Goyang Khas Betawi." Visual Heritage 2(01):9-13.

Farid, R. 2017. "Kajian Strategi Branding Clothing UNKL347." Komunikasi Visual \& Multimedia 8(1):59-81.

Gobe, M. 2010. Emotional Branding Paradigma Baru untuk Menghubungkan Merek Dengan Pelanggan. Jakarta: Erlangga.

Gunawan, F. 2015. "Efektivitas Penggunaan Ashraf \& BCL Sebagai Celebrity Endorser Dalam Iklan Televisi LINE Let 's Get Rich dengan Menggunakan Model TEARS." Jurnal E-Komunikasi 3(2):1-10.

Iswanto, R. 2015. "Pengaruh Brand Image terhadap Keputusan Pembelian pada Photo Cabin." Demandia 1(2):116-133.

Kusrianto, A. 2009. Pengantar Desain Komunikasi Visual. Yogyakarta: Andi.

Kusuma, M. R. P., \& Purnomo, A. S. A. 2020. "Emotional Branding dalam Strategi Pemasaran Kolaborasi : Studi Kasus Desain Kemasan Mizzu 'Khong Guan Face Palette."' Mudra Jurnal Seni Budaya, 35(3):317-322.

Moriarty, S., Mitchell, N., \& Wells, W. 2011. Advertising. Jakarta: Prenadamedia Group. Musaffak. 2015. “Analisis Wacana Iklan Makanan dan Minuman pada Televisi Berdasarkan Struktur Dan Fungsi Bahasa." Jurnal Keilmuan Bahasa, Sastra, Dan Pengajarannya 1(2):224-232

Nurseptia, M. A., \& Trenggana, A. F. M. 2019. “Pengaruh Kualitas Produk, Emotional Branding, dan Experiental Marketing Terhadap Loyalitas Konsumen di Koflcuk Bandung." E-Proceeding of Management 6(3):6203-6214.

Prastika, N. D. 2013. “Emotional Branding Telepon Seluler Merek Nokia Terhadap Konsumen." Jurnal Psikostudia Universitas Mulawarman 2(1):10-15. 
Rachmayanti, A. P., \& Pamungkas, I. N. A. 2017. Penerapan Emotional Branding Pada Iklan Tvc Aqua Versi “ I T'S In M E ". E-Proceeding of Management, 4(1), 10811087.

Ravel, S. 2017. Wuling Mengaku Sudah Mengerti Konsumen Indonesia. www.otomotif.kompas.com/read/2017/08/10/150222815/wuling-mengakusudah-mengerti-konsumen-indonesia (diakses pada 25 maret 2020 pukul 15.10)

Rustan, S. 2013. Mendesain Logo. Jakarta: gramedia pustaka utama.

Silalahi, T. S. 2019. Pemuda Milenial. Sukabumi: Jejak.

Sugiyono. 2016. Metode Penelitian Kuantitatif, Kualitatif, dan R\&D. Bandung: Alfabeta. Suryo, A. A., Suddin, A., \& Widajanti, E. 2019. “Pengaruh Harga, Iklan, Citra Merk, dan Pelayanan Purna Jual terhadap Keputusan Pembelian Mobil Wuling di Wilayah Surakarta." Jurnal Manajemen Sumber Daya Manusia 13(2):395-404.

Tanumiharjo, R. D., Goenawan, F., \& Monica, V. 2019. “Efektivitas Iklan Televisi Telkomsel \#Sebarkansemangat Asian Games 2018 terhadap Masyarakat Surabaya." Jurnal E-KOMUNIKASI 7(1): 1-11

Wijanarka, Y., Suryoko, S., \& Widiartanto. 2015. "Pengaruh Emotional Branding dan Experiential Marketing terhadap Loyalitas Merek Eiger Adventure Melalui Brand Trust dan Kepuasan Pelanggan Sebagai Variabel Intervening (Studi Kasus pada Eiger Adventure Store Semarang)." Jurnal IImu Administrasi Bisnis 4(2):1-12. 